\title{
Spatial distribution of vegetation along the environmental gradient on the coastal cliff and plateau of Janggi peninsula (Homigot), southeastern Korea
}

Song Hie Jung ${ }^{1}$, A Reum Kim', Bong Soon Lim¹, Jae Won Seol ${ }^{1}$ and Chang Seok Lee ${ }^{2^{*}}$ (1)

\begin{abstract}
Background: Cliffs are a major plant habitat around the coastal area, but in contrast to sand dunes and salt marshes, they have been little investigated in Korea. There are simple descriptions of cliff vegetation in studies on island vegetation, but there is no published paper, which addressed sea cliff vegetation synthetically. Furthermore, the coastal area where this study was carried out was designated as a conservation reserve. Even though, this area is exposed to intense recreational use such as trekking in these days.

This study aims to clarify spatial distribution and structure of vegetation along the environmental gradient on coastal cliff and plateau in the Janggi peninsula (Homigot) located on southeastern Korea. Further, this study has also another objective to prepare a restoration plan to protect this conservation reserve from intense human disturbance.

Results: Landscape elements were arranged in the order of sea cliff risen directly on the sea, seashore, coastal cliff, and plateau covered with relatively deep soil in a coastal area of the Janggi peninsula (Homigot), southeastern Korea. Vegetation was sampled at 59 plots arranged from the sea cliff through the seashore and coastal cliff to plateau. The sea cliff, seashore, and coastal cliff, which compose the coastal landscape, were dominated by the seashore spatulate aster (Aster spathulifolius Maxim.) community, dwarf sand sedge (Carex pumila Thunb.) community, and seashore spatulate aster (Aster spathulifolius Maxim.) community. On the plateau corresponding to the ridge of the coastal cliff, black pine (Pinus thunbergii Parl.) community, golden rain tree (Koelreuteria paniculata Laxmann) community, east Asian hackberry (Celtis sinensis Pers.) community, sawleaf zelkova (Zelkova serrata Makino) community, and Korean oak (Quercus dentata Thunb.) community were established in the mentioned order along distance from the sea. Stand ordination showed a vegetation sequence from the seashore through the cliff to the plateau, consistent in its overall pattern among sites. This was dominated by topography. There is evidence for the importance also of salinity, drought and of soil depth.

Conclusion: The lack of scientific interest in cliffs to date is in striking contrast to the commonness of cliffs around the whole national territory and to the attraction cliffs have had for humans throughout history. Cliffs provide a unique habitat, rarely investigated from an ecological viewpoint. Cliffs may represent an invaluable type of ecosystem, consisting of some of the least disturbed habitats on earth and contributing more to the biodiversity of a region than their surface coverage would indicate. Although this coastal area where this study was carried out was designated as a conservation reserve, this area is in danger of severe disturbance due to excessive recreational use. We recommended a restoration plan to protect this area from such a disturbance.
\end{abstract}

Keywords: Environmental gradient, Janggi peninsula (Homigot), Plateau, Sea cliff, Spatial distribution, Vegetation sequence

\footnotetext{
*Correspondence: leecs@swu.ac.kr

${ }^{2}$ Faculty of Environment and Life Sciences, Seoul Women's University, Seoul

01797, South Korea

Full list of author information is available at the end of the article
}

(c) The Author(s). 2019 Open Access This article is distributed under the terms of the Creative Commons Attribution 4.0 International License (http://creativecommons.org/licenses/by/4.0/), which permits unrestricted use, distribution, and reproduction in any medium, provided you give appropriate credit to the original author(s) and the source, provide a link to the Creative Commons license, and indicate if changes were made. The Creative Commons Public Domain Dedication waiver (http://creativecommons.org/publicdomain/zero/1.0/) applies to the data made available in this article, unless otherwise stated. 


\section{Background}

Biodiversity means the myriad life forms found on Earth. These are the legacy of billions of years of evolution, shaped by natural processes and, increasingly, by the activities of humans. Biodiversity is most often understood as the number of different species of plants, animals, and microorganisms in existence. However, biodiversity also encompasses the specific genetic variations and traits within species as well as the ecosystems as a home of all biological species. That is, biodiversity includes genetic, species, and ecosystem diversity (Primack 2008).

The most alarming immediate global threat to life on Earth is that of biological impoverishment caused by an accelerating downward spiral of biodiversity. This spiral, in turn, is driven by accelerating loss of species and their habitats. But considering the fact that major causal factor of biodiversity loss is destruction or deterioration of habitat, mindset shift toward conservation of eco-diversity, which includes biological, ecological, and landscape heterogeneity rather than simple biodiversity to protect rapidly disappearing biodiversity is required urgently (Naveh 1994).

Coastal cliffs are very steep rock faces near the sea. They may ascend in steps and have ledges, crevices, and overhangs. Coastal cliffs may rise directly from the sea or be separated from it by a narrow shore. Cliffs and outcrops provide many varied habitats: from bare rock colonized only by mosses and lichens to deeper soils supporting woody vegetation; from highly exposed situations to heavily shaded and sheltered habitats; and from very dry to permanently wet surfaces. Coastal cliffs are particularly influenced by salt spray, strong wind, or desiccation. Therefore, for halophytes and succulents, the characteristic of these habitats grow there and woody plants are frequently stunted and wind-shorn. Sea cliffs usually start from a rocky tidal platform, rising quickly to a height of $20-30 \mathrm{~m}$. Apart from the presence of a few exotic species, the plant communities in many parts are essentially undisturbed by man (Wilson and Cullen 1986; Kennedy and Dickson 2007; Ramesh et al. 2017).

Cliffs are a major plant habitat around the coastal area, but in contrast to sand dunes (Jung and Kim 1998; Kim et al. 2009; Shin et al. 2015) and salt marshes (Min 1985; Lee and Kim 1988; Ihm 1989; Lee 1989; Ihm et al. 1998a; Ihm et al. 1998b; Kim et al. 2005; Han 2008; Lee et al. 2009; Lee et al. 2012), they have been little investigated in Korea. There are simple descriptions of cliff vegetation in studies on island vegetation (Lee et al. 2003; Song et al. 2008; Song et al. 2009; Choi et al. 2012; Kim 2012; Kim et al. 2013), but there is no published paper, which addressed sea cliff vegetation synthetically.

Most lowlands including coastal area were intensively exploited in Korea where population density is very high. Therefore, it is difficult to find an area equipped with integrating feature of the natural environment except for the protected area. Protected natural areas play a critical role in the conservation of biodiversity and natural capital and the ecological goods and services that accrue from them. While ecosystem management outside protected areas may be directed toward modifying or controlling nature, producing crops, or extracting natural resources, management efforts within protected areas are directed at maintaining ecosystems in as a natural state as possible (Stolton et al. 2015). This study was carried out in a protected area designated for the conservation of black jetbead (Rhodotypos scandens Makino) community and golden rain tree (Koelreuteria paniculata Laxmann) community.

This study aims to clarify spatial distribution and structure of vegetation along the environmental gradient on coastal cliff and plateau in the Janggi peninsula (Homigot) which is designated as a protected area. Further, this study has also another objective to prepare a restoration plan to protect the conservation reserve from intense human disturbance.

\section{Materials and methods Study areas}

This study was carried out around Balsan-ri and Daedongbae-ri located on the northwestern tip of the Janggi peninsula, southeastern Korea (Fig. 1). This area is designated as the protected area for conservation of black jetbead community and golden rain tree community, and thereby, the natural environment is relatively conserved well compared with the other coastal area of this peninsula. Mountainous hills of $180-200 \mathrm{~m}$ in above sea level including Mt. Gonggae $(214.6 \mathrm{~m})$ and Mt. Woomuljae are distributed in a row in this area. Geology of this area is usually composed of Yangbukgun and Youngilgun strata attributed to the tertiary period of the Cenozoic era, basalt flow attributed to the quaternary of the Cenozoic era, and terrace deposit.

The area has an equable climate. Mean annual temperature and precipitation of this area are $14.2{ }^{\circ} \mathrm{C}$ and $1152.0 \mathrm{~mm}$, respectively. Winds are relatively strong as annual mean wind speed is $10.08 \mathrm{~km} / \mathrm{h}$. Wind direction is very variable but westerly wind usually dominates wind direction and easterly one is prevailing during summer season (Korea Meteorological Administration 2011). But this area is located on the coast so that most cliffs are exposed to the land-sea breeze occurring every day.

\section{Methods \\ Vegetation sampling}

Five transects running from the sea through sea cliff, shore, and coastal cliff to plateau were installed with $100 \mathrm{~m}$ and 20 $\mathrm{m}$ in length and width, respectively. In each transect, species presence was recorded, and cover degree estimated following Braun-Blanquet (1964). Vegetation data were collected in 59 plots, measuring $2 \times 2 \mathrm{~m}$ (grassland) and $10 \times 10 \mathrm{~m}$ (forest). A vegetation survey was carried out from May to September 2018. All the plant species occurred in each plot were 


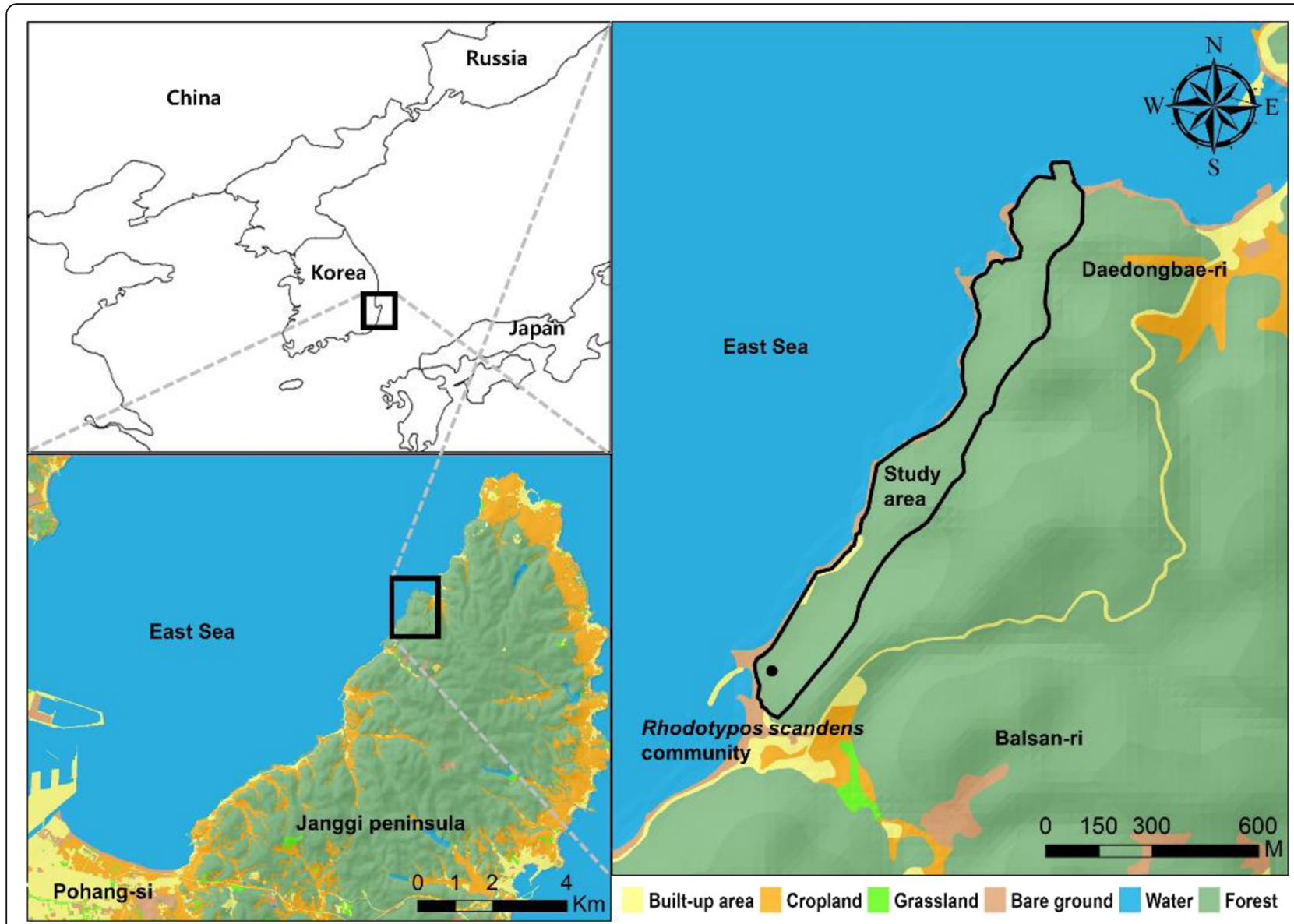

Fig. 1 The study area, Janggi peninsula (Homigot), southeastern Korea

identified, following Lee (1985), Park (1995), and Korea National Arboretum (2003). The placement of transects was necessarily limited by accessibility, but the non-accessible parts viewed through binoculars seemed similar.

\section{Soil sampling and analysis}

A soil sample was taken from each quadrat if enough soil was accessible. Soil sample was taken in five sites for forest vegetation, golden rain tree (Koelreuteria paniculata Laxmann) community, black pine (Pinus thunbergii Parl.) community, east Asian hackberry (Celtis sinensis Pers.) community, sawleaf zelkova (Zelkova serrata Makino) community, and Korean oak (Quercus dentata Thunb.) community and in one site for vegetation established on the sea cliff, seashore, and coastal cliff. Conductivity was measured as environmental factors for interpreting vegetation sequence along the environmental gradient.

Soil samples were collected from the top $10 \mathrm{~cm}$ at five random points in each plot, pooled, air-dried at room temperature, and sieved though 2-mm mesh. Conductivity in a 1:5 w/v mixture of soils and deionized water was measured with a portable conductivity meter (HI9033, Hanna Instrument).

\section{Statistical analyses}

The differences in species composition among plant communities established in the study area were analyzed with DCA ordination (ter Braak 1987). For ordination, the cover degree of each species was converted to the median value of percent cover range in each cover class. Relative coverage was determined by multiplying by 100 to the fraction of each species to the summed cover of all species in each plot (Klaudisova and Osbornova 1990). The relative coverage of each species was then regarded as the importance value (Curtis and McIntosh 1951). Finally, a matrix of importance values for all species in all plots was constructed and it was subjected to Detrended Canonical Correspondence Analysis (DCA) for ordination (ter Braak 1987).

Comparisons of life form composition among plant communities were also carried out by applying the abovementioned ordination method based on dormancy, disseminule, growth, and radicoid form data.

Kruskal-Wallis test (a non-parametric ANOVA) in SPSS ver. 12.0 (SPSS Inc. 2003) was used to compare the differences in means of soil properties among study sites. 


\section{Results}

\section{Spatial distribution of vegetation}

Landscape elements were arranged in the order of sea cliff risen directly on the sea, seashore, coastal cliff, and plateau covered with relatively deep soil in a coastal area of the Janggi peninsula (Homigot), Southeastern Korea (Figs. 2 and 3).

Sea cliffs were dominated by the seashore spatulate aster (Aster spathulifolius Maxim.) community and wichura's rose (Rosa wichuraiana Crep. ex Franch. \& Sav.), beach morning glory (Calystegia soldanella Roem. \& Schultb.), coastal green bristlegrass (Setaria viridis var. pachystachys Makino \& Nemoto), and narrow-leaved plantain (Plantago lanceolata L.) and also showed high coverage there (Fig. 4). The seashore, which is located between the sea and coastal cliff, was occupied by dwarf sand sedge (Carex pumila Thunb.) community, Komarov's Russian thistle (Salsola komarovii Iljin) community, beach vitex (Vitex rotundifolia L.f.) community, wichura's rose community, and beach morning glory community (Fig. 5). Between the seashore and coastal cliff, the golden rain tree community was established and occasionally Korean wormwood (Artemisia princeps var. orientalis) community also appeared (Fig. 6). Coastal cliffs near to the sea were occupied by the seashore spatulate aster community, wichura's rose community, coastal moss-like stonecrop (Sedum oryzifolium Makino) community, beach morning glory community, and Chinese juniper (Juniperus chinensis L.) community (Fig. 7). On the plateau corresponding to the ridge of the coastal cliff, black pine (Pinus thunbergii Parl.) community, east Asian hackberry (Celtis sinensis Pers.) community, sawleaf zelkova (Zelkova serrata Makino) community, and Korean oak (Quercus dentata Thunb.) community were established in the mentioned order along distance from the sea (Fig. 8). Golden rain tree community also appeared on the plateau, and the topographic position of the community was similar to that of the black pine (Fig. 6).

\section{Species composition of vegetation}

Species composition of each site including reference and restored ones is given in the Appendix. The seashore spatulate aster community established on the sea cliff is dominated by the seashore spatulate aster and narrow-leaved plantain, and coastal green bristle grass appears in high frequency and coverage. On the other hand, wichura's rose and sea wheatgrass (Elymus mollis Trin.) besides narrow-leaved plantain appeared also in high frequency and coverage in the seashore spatulate aster community established on the coastal cliff.

In dwarf sand sedge community, wichura's rose, beach morning glory, and Asian dayflower (Commelina communis L.) occupied high frequency as well as coverage

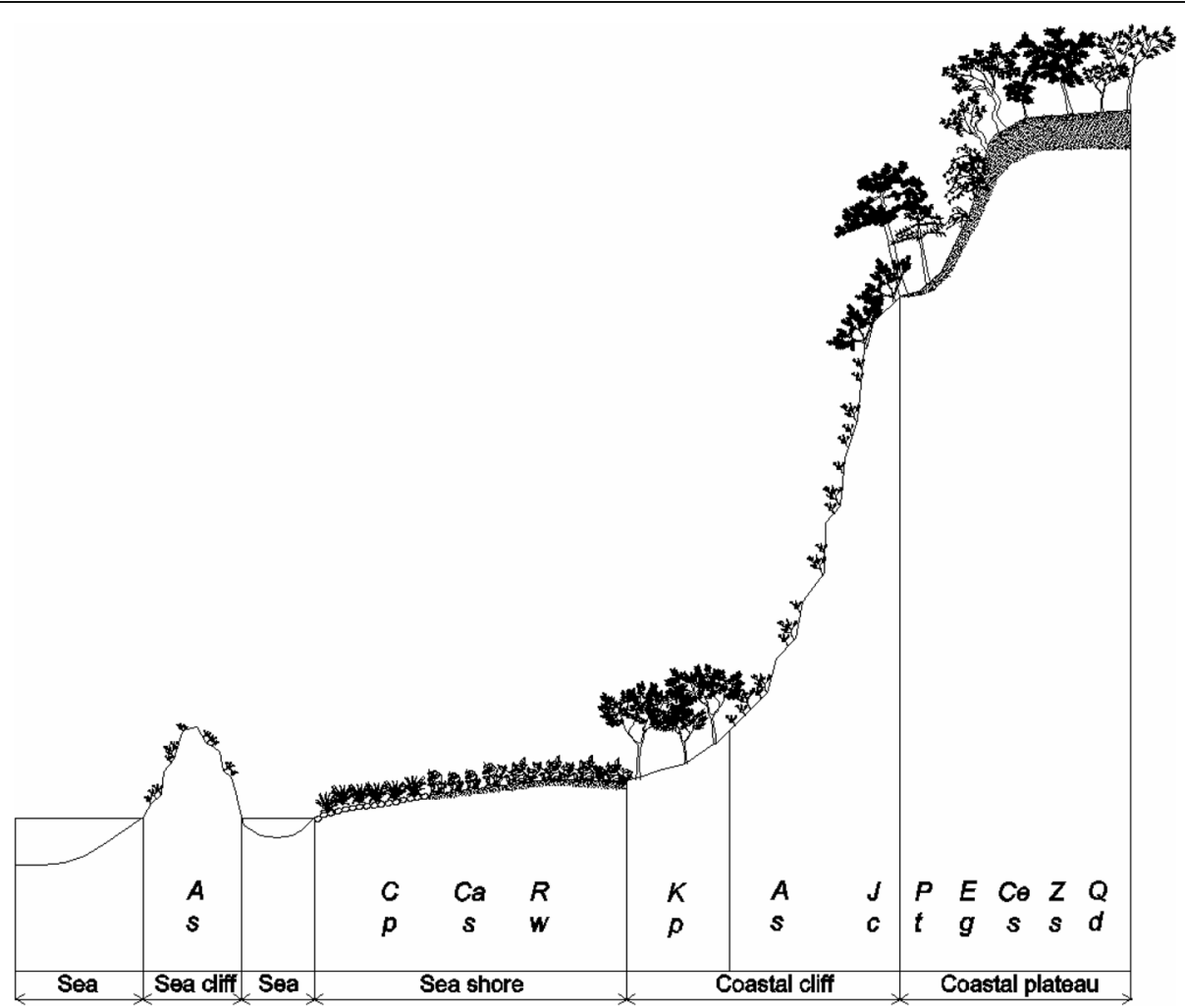

Fig. 2 A diagram showing vegetation profile established from sea cliff through the seashore and coastal cliff to coastal plateau in Janggi peninsula (Homigot), southeastern Korea. A.s Aster spathulifolius, C.p Carex pumila, Ca.s Calystegia soldanella, R.w Rosa wichuraiana, K.p Koelreuteria paniculata, J.c Juniperus chinensis, P.t Pinus thunbergii, E.g Elaeagnus glabra, Ce.s Celtis sinensis, Z.s Zelkova serrata, Q.d Quercus dentata 


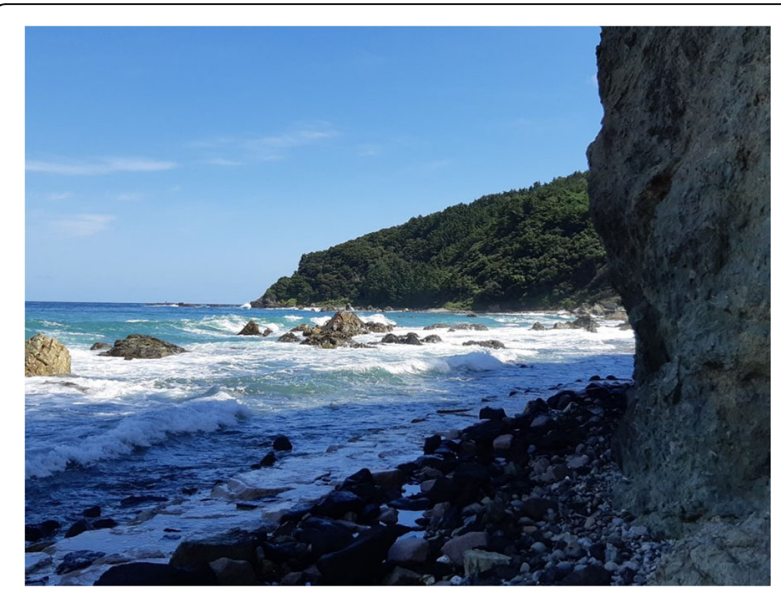

Fig. 3 A photo showing the whole landscape of the study area. Landscape elements are arranged in the order of sea cliff risen directly on the sea, shore composed of gravel and sand, coastal cliff, and plateau as it moves from sea to inland area

except for dominant species. Wichura's rose and prickled-vine smartweed (Persicaria senticosa $\mathrm{H}$. Gross ex Nakai) occupied high frequency as well as coverage except for dominant species in beach morning glory community. Komarov's Russian thistle formed a community with beach morning glory and wichura's rose. In beach vitex community, the beach vitex is mixed with wichura's rose and in wichura's rose community, the seashore spatulate aster, dwarf sand sedge, and Korean wormwood occupy high frequency as well as coverage except for dominant species.

On the plateau with relatively deep soil, black pine community, golden rain tree community, east Asian hackberry community, sawleaf zelkova community, and Korean oak community are established. In black pine community, Korean oak, east Asian hackberry, broad-leaf oleaster (Elaeagnus macrophylla Thunb.), chopi (Zanthoxylum piperitum DC.), wichura's rose, Asian dayflower, and skunk vine (Paederia scandens Merr.) appear frequently.

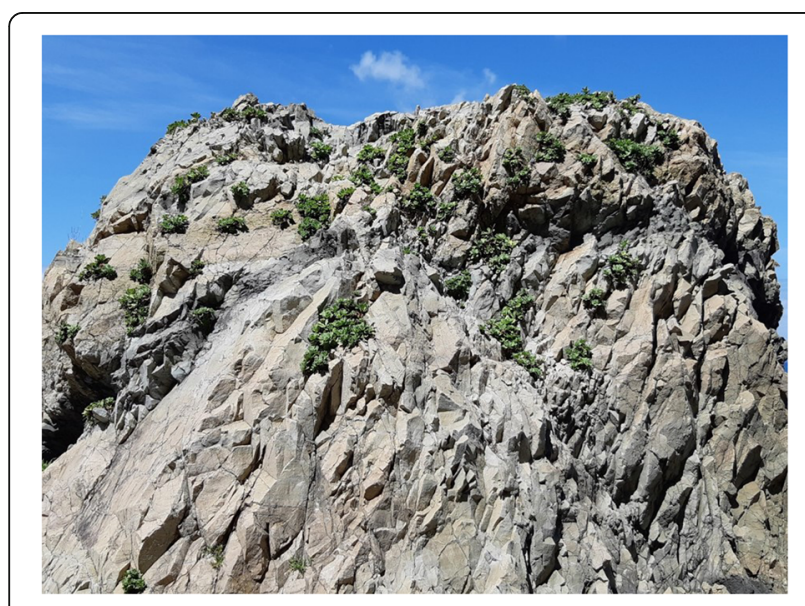

Fig. 4 Aster spathulifolius community established on the sea cliff

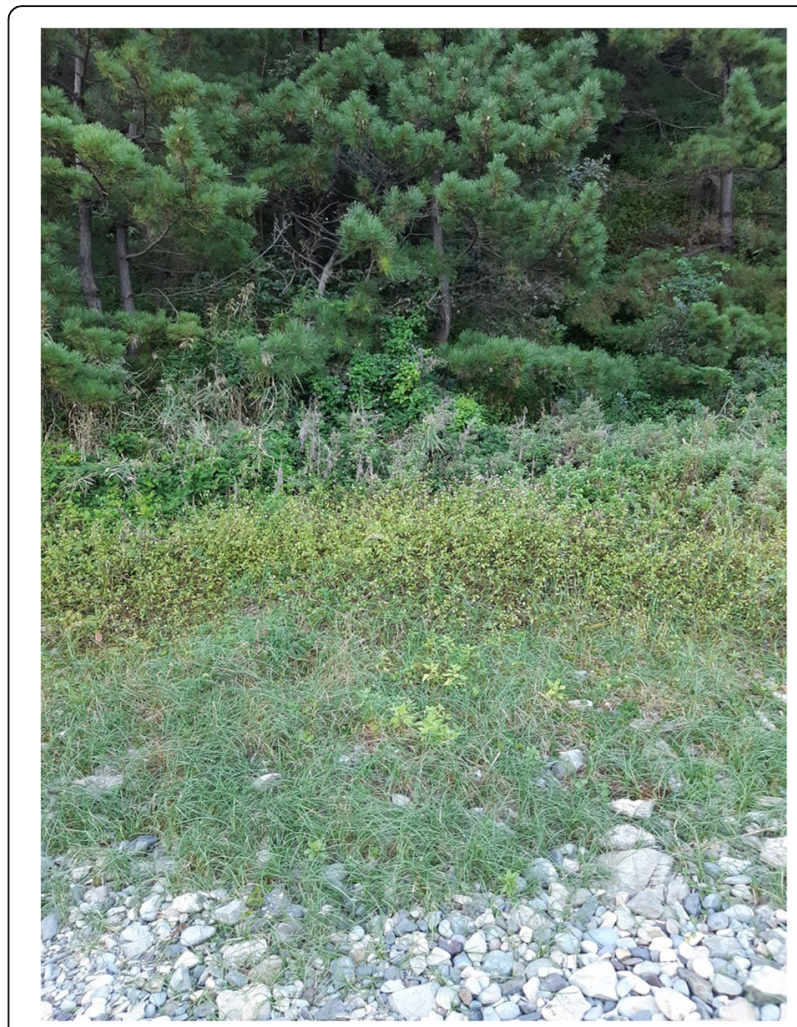

Fig. 5 Carex pumila community established on the seashore

In golden rain tree community, sawleaf zelkova, east Asian hackberry, broad-leaf oleaster, wichura's rose, northern dendranthema (Dendranthema boreale Ling ex Kitam.), and skunk vine appear in high frequency and coverage and form a community with dominant species.

In east Asian hackberry community, broad-leaf oleaster, Chinese winter-berry currant (Ribes fasciculatum var. chinense Maxim.), Asian dayflower, and wavy-leaf basket grass (Oplismenus undulatifolius P. Beauv.) occupied high

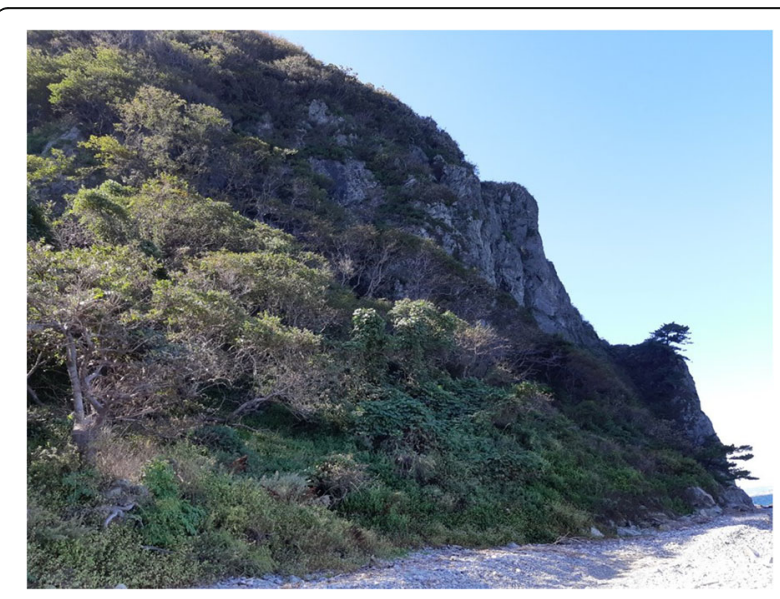

Fig. 6 Koelreuteria paniculata community established on a concave topography between the seashore and coastal cliff 


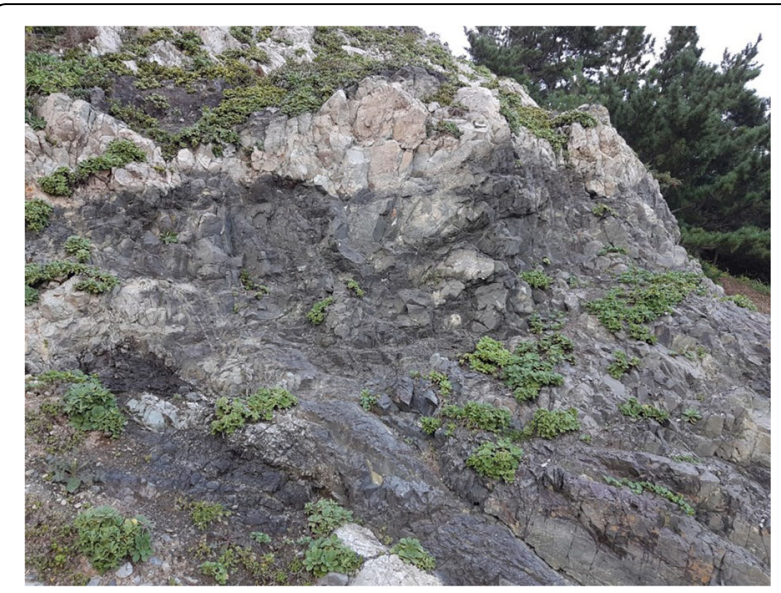

Fig. 7 Aster spathulifolius community established in crevices, ledges, and overhangs of the coastal cliff

frequency as well as coverage except for dominant species. In sawleaf zelkova community, Chinese winter-berry currant, border privet (Ligustrum obtusifolium Siebold \& Zucc.), Asian dayflower, and wavy-leaf basketgrass showed high frequency as well as coverage besides dominant species. In Korean oak community, blunt-lobe spicebush (Lindera obtusiloba Blume), Korean pepper (Zanthoxylum piperitum), border privet, Asian dayflower, and wavy-leaf basketgrass occupied high frequency as well as coverage except for dominant species.

\section{Vegetation and environment}

As the result of stand ordination based on species composition data of each plant community, stands tended to be arranged in the order of vegetation types established on the plateau, seashore, and sea and coastal cliffs on the axis I. Ordination scores follow the topography closely (Fig. 9). That is, there is clear environmental control of species composition of vegetation. Vegetation types established on cliffs were divided again into the upper and lower parts on axis II. Vegetation types clustered in the upper part were established on a hard cliff, whereas ones in the lower part were established on a soft cliff.

The conductivity of soil collected from major plant communities established from the sea cliff through the seashore and coastal cliff to coastal plateau showed a variation depending on topography. The conductivity was higher in the soil from plant communities established on a sea cliff, coastal cliff, and fringe of a coastal plateau, whereas was relatively lower than that from plant communities established on the seashore and coastal plateau (Fig. 10). This conductivity level was lower compared with that in salt marsh soil (Min 1985), while was similar to that in coastal sand dune (Kim et al. 2009).

As the result of stand ordination based on dormancy form composition, stands dominated by chamaephytes $(\mathrm{Ch})$ and hemicryptophytes $(\mathrm{H})$ were clustered in the left part and ones by megaphanerophytes (MM) and therophytes (Th) were in the right part on axis I. On axis II,
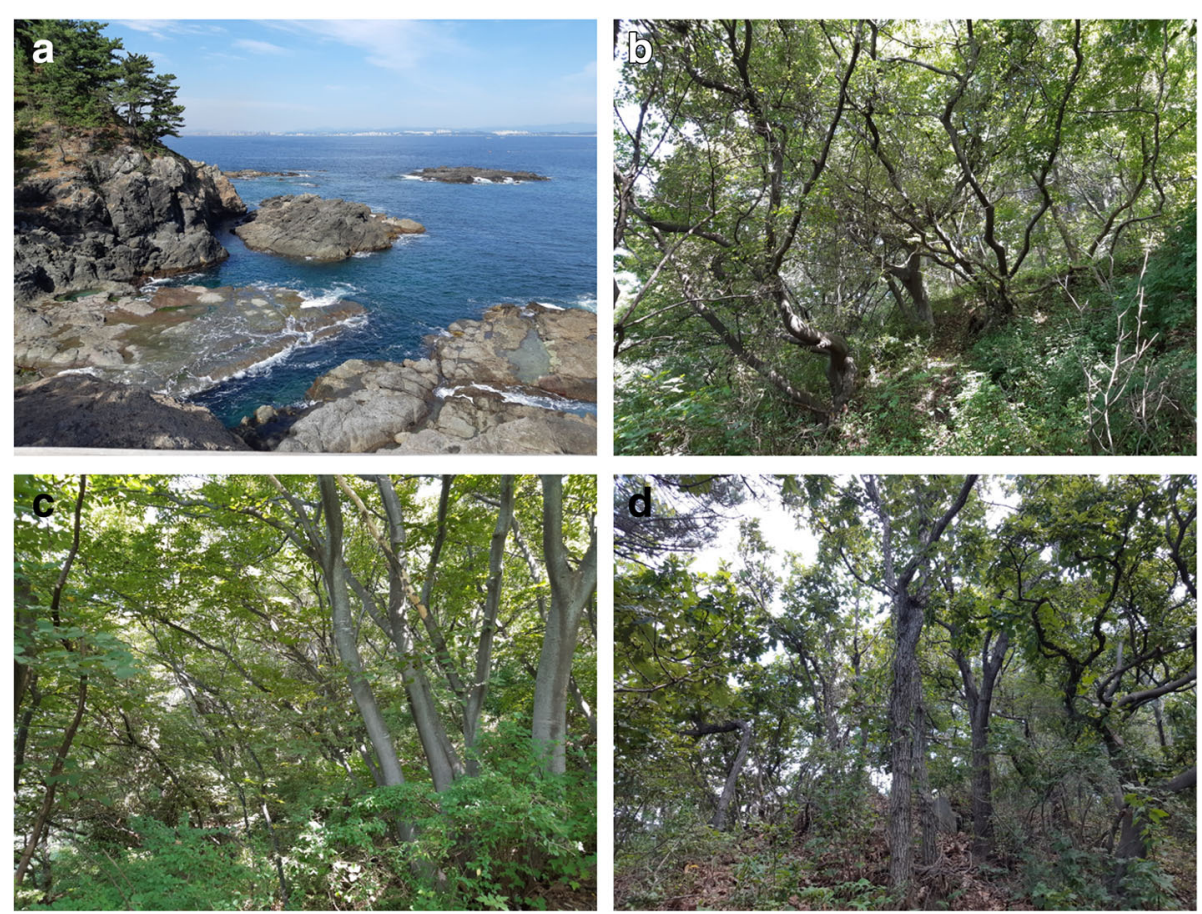

Fig. 8 Pinus thunbergii community and Juniperus chinensis community on the fringe of the coastal plateau (a), Celtis sinensis community on the fore-end slope of the coastal plateau (b), Zelkova serrata community on the slope of the coastal plateau (c), and Quercus dentata community on the ridge of the coastal plateau (d) 


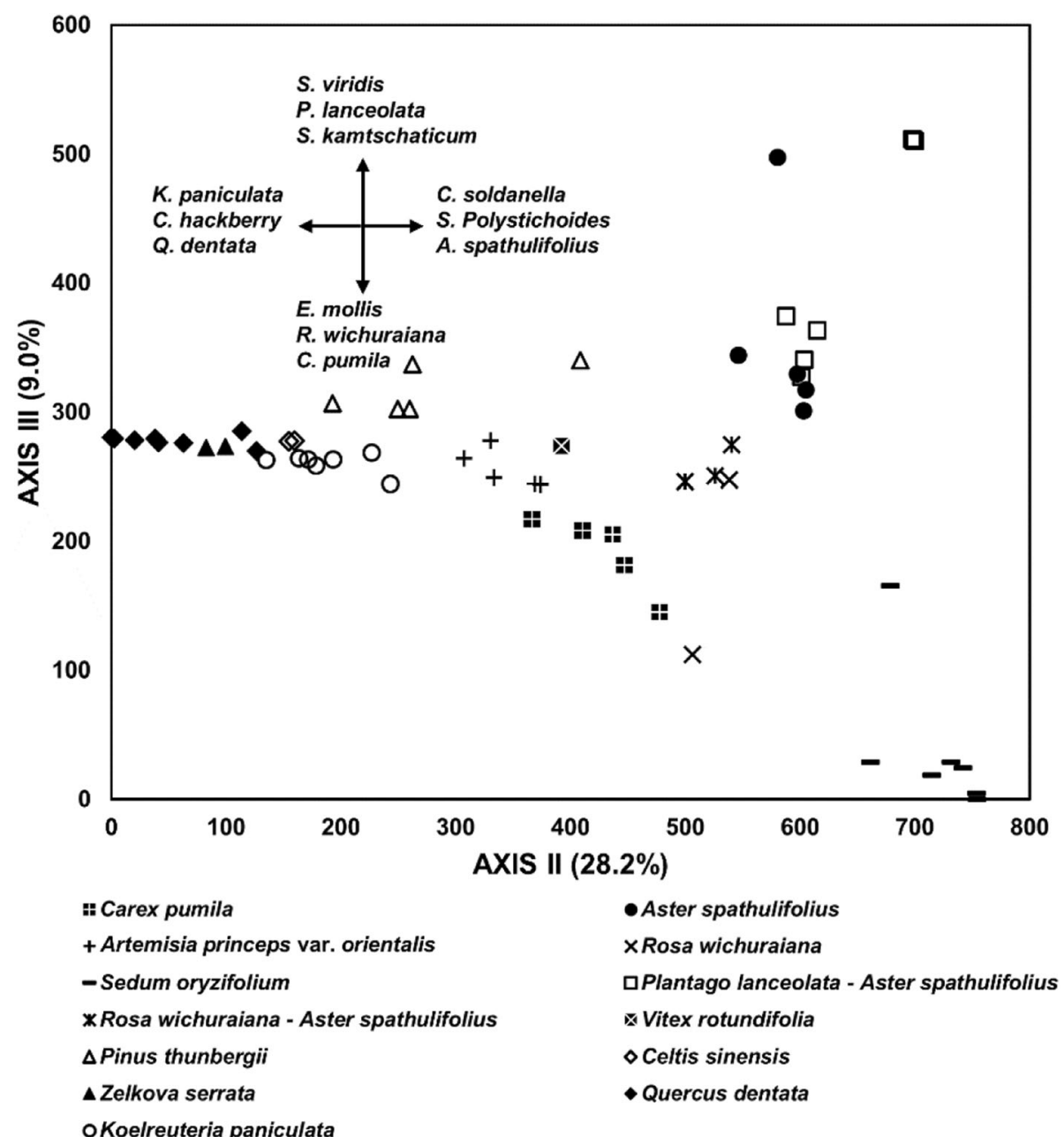

Fig. 9 Ordination of study plots based on vegetation data collected from sea cliff through the seashore and coastal cliff to coastal plateau in Janggi peninsula (Homigot), southeastern Korea

stands tended to be divided into nanophanerophytes (N, upper) and geophytes (G, lower) dominated stands, respectively (Fig. 11). In the result of stand ordination based on growth form composition, stands were divided into branched form ( $b$, left), and erect (e) and branched-procumbent forms (b-p, lower) dominated stands on axis II (Fig. 11). In the result of stand ordination based on radicoid form composition, stands tended to be divided into $R_{5}$ (non-clonal growth, monophyte) form (upper), and $R_{2}$ (moderate extent) and $R_{3}$ (narrowest extent) forms (lower) dominated stands on axis III (Fig. 11). In the result of stand ordination based on disseminule form composition, stands tended to be divided into $D_{2}$ (disseminated attaching with or eaten by animals and man) form (left) and $D_{1}$ (disseminated widely by wind and water) form (right) dominated stands on axis II (Fig. 11). As the result of stand ordination based on all life forms data including dormancy, growth, radicoid, and disseminule forms, the spatial distribution of stands showed a similar trend to the result based on each life form (Fig. 11).

In the results of stand ordination based on life-form composition abovementioned, stands tended to be divided into plant communities established on the plateau and those on cliffs and shore relatively clearly. On the other hand, plant communities established on the cliffs and the shore were also divided with each other although it is not clear as much as the result of the former.

\section{Discussion}

Vegetation sequence and environmental gradient

Spatial distribution of vegetation in coastal cliffs and plateau of Janggi peninsula (Homigot) tended to be arranged in the order of grassland, shrubland, and forest from the coastal beach through the cliff to plateau. Grassland was composed of dwarf sand sedge community, Komarov's Russian thistle community, beach morning glory community, 


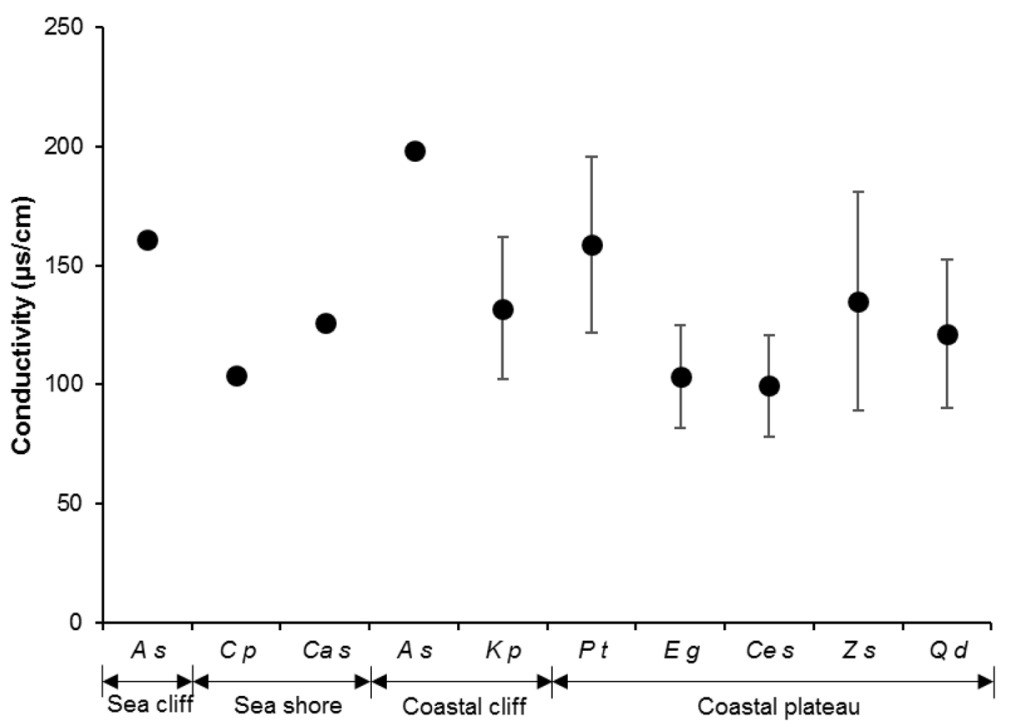

Fig. 10 Conductivity gradient of soil collected from major plant communities established from sea cliff through the seashore and coastal cliff to coastal plateau in Janggi peninsula (Homigot), southeastern Korea. A.s Aster spathulifolius, C.p Carex pumila, Ca.s Calystegia soldanella, K.p Koelreuteria paniculata, P.t Pinus thunbergii, E.g Elaeagnus glabra, Ce.s Celtis sinensis, Z.s Zelkova serrata, Q.d Quercus dentata

seashore spatulate aster community, coastal moss-like stonecrop community, and Korean wormwood (Artemisia princeps var. orientalis Hara) community. Among them, the former two communities were established on the seashore and seashore spatulate aster community and coastal moss-like stonecrop community were on the cliff. Meanwhile, beach morning glory community is established in both sites and Korean wormwood community appears occasionally on the ecotone between both zones. Shrubland was composed of wichura's rose community and beach vitex community. Among them, the former community is established in both sites and the latter community on the seashore. Forest was composed of golden rain tree community, black pine community, East Asian hackberry community, sawleaf zelkova community, and Korean oak community. Spatial distribution of plant communities composing forest tended to appear in the mentioned order from the sea but golden rain tree community and black pine community is established on both of the lower and the upper parts of cliffs.

The result of stand ordination gives a vegetation sequence depending on the distance from the sea (Fig. 9). Stand position in the sequence is correlated with distance from the sea, stands with low scores being outer ones, whereas them with high scores being inner ones. The species with highest scores on the ordination are therefore those that tend to occur nearer the sea. They are typical halophytes or desiccation tolerance (Partridge \& Wilson 1975) that are also able to grow on the sea and coastal cliffs as well as the seashore. Stand ordination showed a vegetation sequence from the seashore through the cliff to the plateau, consistent in its overall pattern among sites. This was correlated with topography (Fig. 2). It would be also related to salinity, drought, and soil depth (Wilson and Cullen 1986).

Coastal cliffs and plateau of Janggi peninsula (Homigot) are covered with halophytes, succulents, and stunted and wind-shorn woody plants. The seashore spatulate aster, moss-like stonecrop, and east Asian hackberry represent each functional type, respectively. Distribution of such vegetation reflects that the habitats are under the influences of salt spray, desiccation, and strong wind. In reality, salinity of soil collected in the study area was higher than that of soil from plant communities established on sea cliff, coastal cliff, and fringe of coastal plateau, which receive salt spray directly, while was lower than that from plant communities established on the seashore and coastal plateau, which is under the indirect influence of salt spray. On the other hand, the appearance of succulent, pubescent, and wind-shorn woody plants reflects that the habitat is under dry and strong wind condition as well (Fig. 10).

Salt spray is important in cliff communities (Hepburn 1943; Wilson and Cullen 1986), but little is known of its intensity, distribution, and variability as it is difficult to measure (Rozema et al. 1983). Our preliminary investigation here shows the expected (Goldsmith 1973) pattern of a higher salt load on the cliffs, while the lower load on the seashore and plateau (Fig. 10). However, salt spray will be very variable and a survey over many months, through varying weather conditions, would be necessary before any correlations could be made. It is possible that the vegetation 

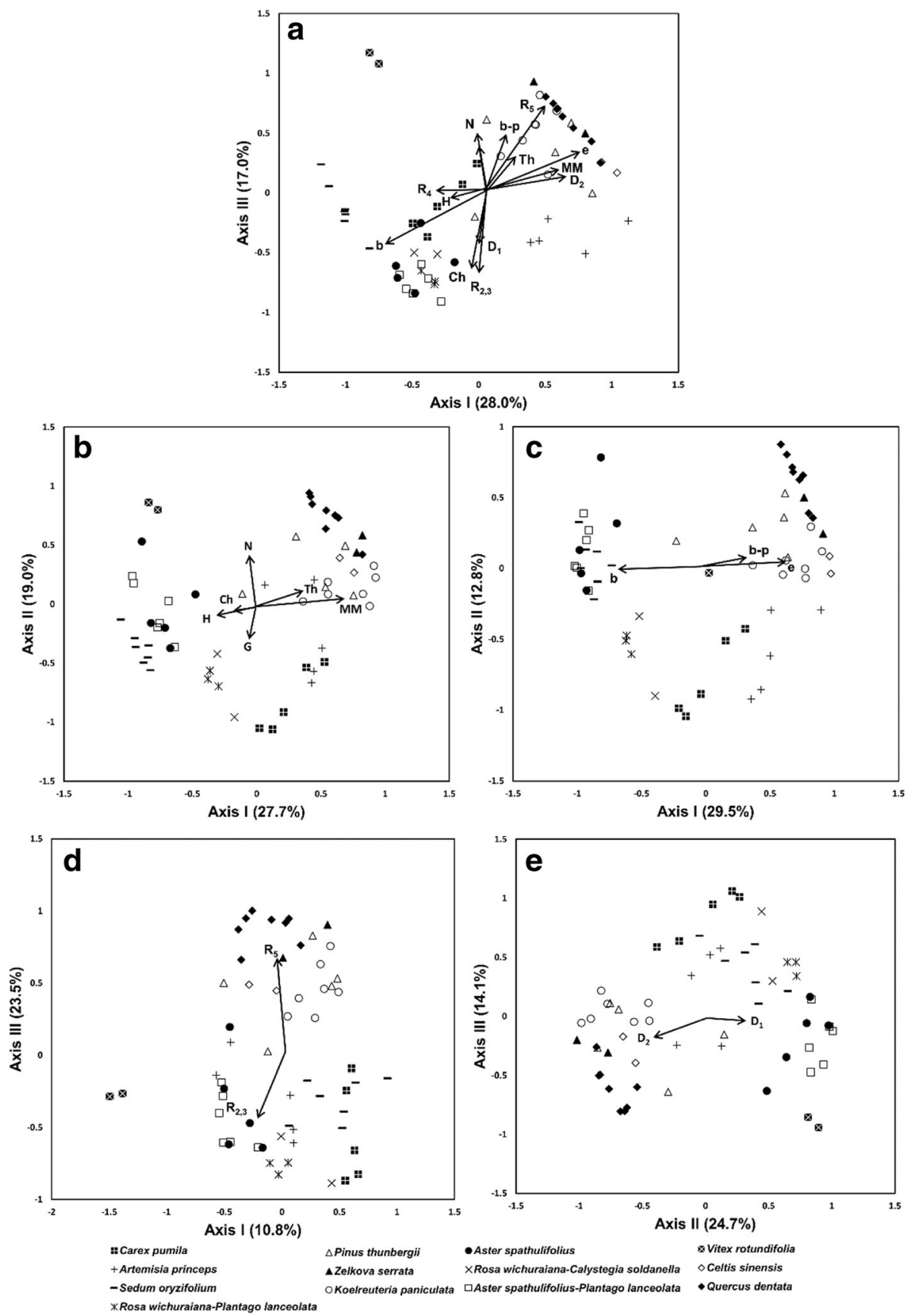

Fig. 11 a-e Ordination of study plots based on dormancy, growth, radicoid, and disseminule forms data of plant species composing vegetation established from sea cliff through the seashore and coastal cliff to coastal plateau in Janggi peninsula (Homigot), southeastern Korea. (a): Total, (b): Dormancy, (c): Growth, (d): Radicoid, (e): Disseminule

patterns are determined by salt spray conditions that occur only infrequently, say once a decade. We do not know whether the species differ in their tolerance of salt spray, though this is commonly assumed to be the cause of species zonation on coastal cliffs including the seashore and plateau.

This work gives only a preliminary description of the coastal cliff vegetation. It points to the need for further work, on the macro- and micro-distribution of cliff species, on the environment, especially in relation to spray, and on the environmental tolerance of the cliff species.

\section{Characteristics and importance of coastal cliff}

The coastal cliffs are characterized by vertical or near-vertical rock faces rising from the sea. Because of their relative inaccessibility, the vertical cliffs rising from 


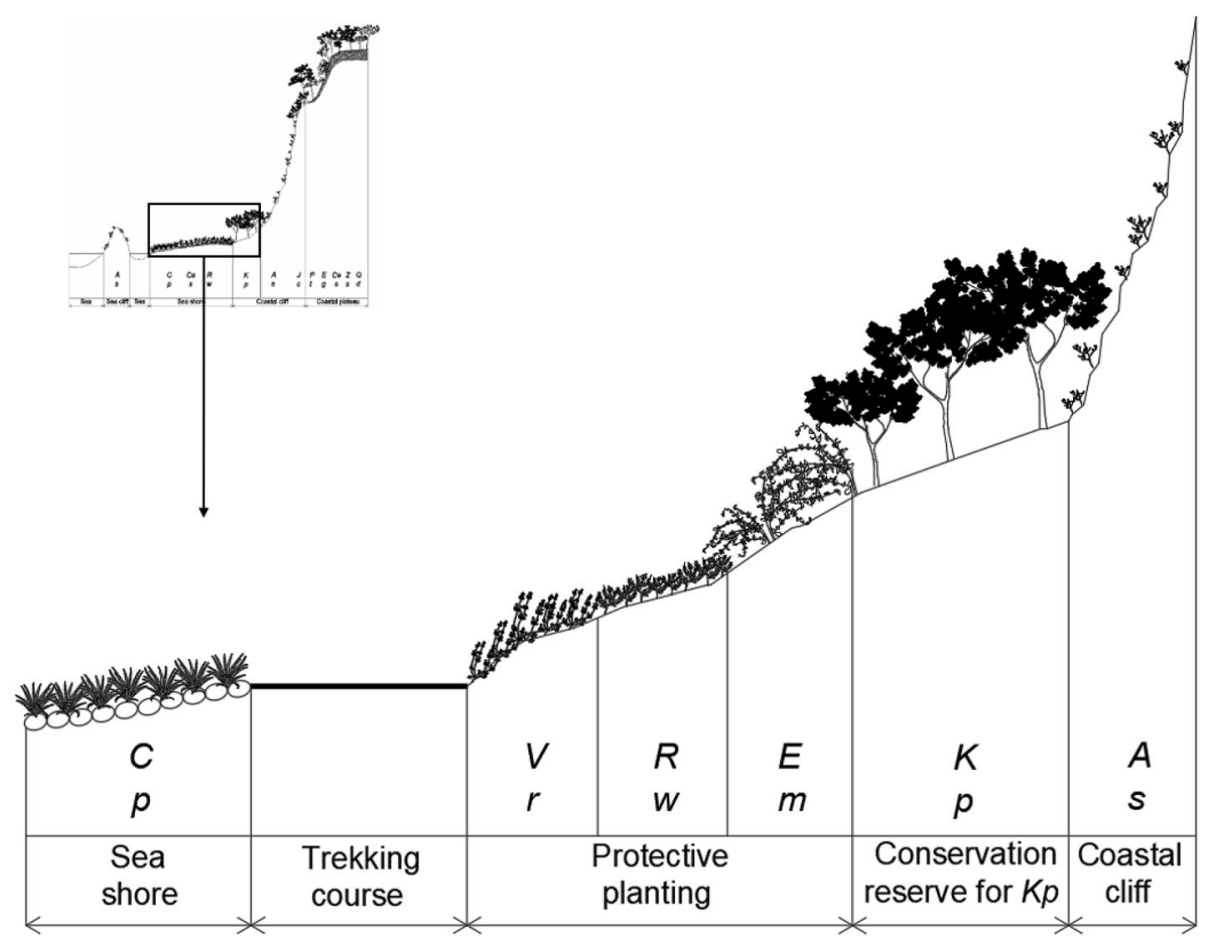

Fig. 12 A restoration plan to protect conservation reserve for Koelreuteria paniculata from intense recreational use for trekking course developed in recent years

the sea provide important refuges for many threatened and/or specialized species, including many endemics. Within the cliff systems are found examples of many unusual coastal habitats, including clay slopes, boulder screes, and rocky ledges on the cliff faces. Because of the heterogeneity of the terrain, mosaics of assemblage form, giving rise to a very rich biodiversity (Wilson and Cullen 1986; Doody 2001; Larson et al. 2005; Ramesh et al. 2017).

Maritime cliffs are the vertical slopes on which the coastline formed after many years of slippage and/or coastal erosion. The geology of the cliffs can range from hard to soft cliffs. The hard cliffs will often consist of granite, sandstone, or limestone and tend to support fewer plants other than in crevices, on ledges or on a break in the slope where the soil is able to accumulate. Softer cliffs consist of less resistant rocks such as shales or boulder clay; the slopes are often less steep allowing for vegetation to easily colonize. Softer cliffs are more prone to erosion or landslides, which is an important factor in the ecology of the community that relies on a large proportion of pioneering plants to quickly re-establish after a landslide. The composition of plants depends on the soil type, ground stability, water source, and the level of exposure to wind and sea-spray. Erosion is an important factor for the plant community on soft cliffs. The high frequency of pioneer plants allows cliff-dwelling species to retreat along with the cliff line itself; however, heavy trampling from recreational use can be devastating to the plant community. If a large area is subject to or frequently subject to slippage, it can wash away plants reducing the ability for the area to regenerate (Andrew et al. 1985; Ramesh et al. 2017). Therefore, vegetation coverage is usually very low on both hard and soft cliffs.

Intense recreational use close to cliffs has caused for introduced species to affect the vegetation composition and reducing the biodiversity. Climate change may have an impact through increased frequency of storms affecting the less resilient plant species (Jones et al. 2013).

In recent years, many trekking courses are developed newly as trekking become popular among citizens. Among them, the shoreline emerged as one of the most popular courses. Janggi peninsula, where this study was carried out, corresponds to a new course created in recent years as well. Since then, not only an ecological link between the seashore and cliff began to fragment but also exotic plants start to invade there. In addition, kind as well as the amount of garbage also increased as visitors increased. Subsequently, course management practiced removing garbage acts as an additional interference and thus incite another disturbance. But this area is a protected area designated to protect communities of two rare plants, black jetbead and golden rain tree. In this respect, systematic as well as synthetic management for this protected area are required urgently. 
As was emphasized in the (Millenium Ecosystem Assessment 2005), the earth's natural capital produces all of those ecosystem goods and services upon which human society and well-being are completely dependent. At the same time, the degradation of ecosystems is widespread.

In general, protected areas are established to protect natural heritage for all citizens to experience, discover, learn, and appreciate into the future. Despite the goal, protected areas rarely contain complete, unaltered ecosystems, particularly lowland where land is used intensively. The ecological integrity of protected areas, and thus their ability to conserve biodiversity and natural capital, faces a number of threats. Incompatible land uses adjacent to protected areas, habitat fragmentation, and invasive alien species are the most commonly reported threats to protected areas. Other stresses such as effects of air, water, and soil pollution and global climate change contribute further to the degradation of protected area's ecosystems and the loss of ecological integrity (Stolton et al. 2015).

\section{Ecological management of the protected area}

Ecological restoration can offer a way of halting and reversing ecological degradation. Effective ecosystem-based management usually requires that ecosystems be managed with minimal intervention and that efforts to maintain ecological integrity and reduce or eliminate threats to it should precede restoration efforts. However, ecological values of a protected area should be restored where they threatened or degraded. Ecological restoration, broadly, contribute to the conservation objectives of protected area management by ensuring these areas contribute to safeguard biodiversity and natural capital and provide ecosystem services into the future. It strives to improve the biological diversity of degraded landscape, increases the populations and distribution of rare and threatened species, enhance landscape connectivity, increase the availability of environmental goods and services, and contribute to the improvement of the human well-being (SERI and IUCN Commission and Ecosystem Management 2004, Gann and Lamb 2006, Canadian Parks Council 2007, Aronson et al. 2016, McDonald et al. 2016).

Our restoration plan is based on the restoration primers mentioned above. We recommend a protective planting by introducing mantle vegetation on the margin of trekking course as a restoration plan to protect this conservation reserve from human interferences according to trekking (Fig. 12). We suggest beach vitex, wichura's rose, broad-leaf oleaster, which composes mantle vegetation in this area as plants to be introduced for protective planting. But golden rain tree community needs natural disturbance such as tidal wave to a degree for sustaining the community as it is in early successional stage (Lee et al. 1993). Therefore, moderate planting is required as excessively dense planting rather can induce another problem. In addition, a consideration that makes this community continuously under the influence of the natural disturbance is also required. It is to use the trekking course in its natural state without any artificial modification.

\section{Conclusion}

The lack of scientific interest in cliffs to date is in striking contrast to the commonness of cliffs around the whole national territory and to the attraction cliffs have had for humans throughout history. Cliffs provide a unique habitat, rarely investigated from an ecological viewpoint. Cliffs may represent an invaluable type of ecosystem, consisting of some of the least disturbed habitats on earth and contributing more to the biodiversity of a region than their surface coverage would indicate. But they are in danger of destruction before the ecological value is clarified. Many trekking courses are developed newly around the coastal area as trekking become popular among citizens in recent years. Although the coastal area where this study was carried out was also designated as a conservation reserve, this area is in danger of severe disturbance due to excessive recreational use. Both through field survey and systematic conservation plan are required urgently. This work gives only a preliminary description of the coastal cliff vegetation. It points to the need for further work in diverse viewpoints.

\section{Appendix}

Species composition of 13 plant communities established on the coastal area, the Janggi peninsula (Homigot), southeastern Korea. Numbers indicate community name. Numbers in parenthesis indicate the number of plots that vegetation survey was carried out

\section{Acknowledgements \\ Not applicable. \\ Funding \\ This study was supported from Pohang Institute of industry and technology, POSCO.}

Availability of data and materials

The datasets generated during and/or analyzed during the current study are available from the corresponding author on reasonable request.

Authors' contributions

LCS designed the study. LCS, JSH, KAR, LBS, and SJW collected and analyzed the data. JSH and LCS wrote the initial draft of the manuscript. All authors read and approved the final manuscript.

\section{Ethics approval}

Not applicable.

\section{Consent for publication}

Not applicable.

\section{Competing interests}

The authors declare that they have no competing interests. 


\section{Publisher's Note}

Springer Nature remains neutral with regard to jurisdictional claims in published maps and institutional affiliations.

\section{Author details}

${ }^{1}$ Graduate School of Seoul Women's University, Seoul 01797, South Korea.

2Faculty of Environment and Life Sciences, Seoul Women's University, Seoul 01797, South Korea.

Received: 11 February 2019 Accepted: 19 March 2019

Published online: 15 April 2019

\section{References}

Andrew J, Malloch C, Bamidele JF, Scott AM. The phytosociology of British seacliff vegetation with special reference to the ecophysiology of some maritime cliff plants. Vegetatio. 1985;62:309-17.

Aronson JC, Blatt CM, Aronson TB. Restoring ecosystem health to improve human health and well-being: physicians and restoration ecologists unite in a common cause. Ecol Soc. 2016;21(4):39.

Braun-Blanquet J. Pflanzensoziologie, Grundzüge der Vegetationskunde. Dritte Auflage ed. Wien-New York: Springer Verlag; 1964.

Canadian Parks Council. Principles and guidelines for ecological restoration in Canada's protected natural areas. Quebec: National Parks Directorate Parks Canada Agency Gatineau; 2007.

Choi BK, Kim JW, Kim SY, Lim JC. Vegetation of Jangdo Island. Kor J Env Eco. 2012;26(4):512-27.

Curtis JT, McIntosh RP. An upland forest continuum in the prairie-forest border region of Wisconsin. Ecology. 1951;32:476-98.

Doody PJ. Sea cliffs \& sea cliff vegetation. In: Doody PJ, editor. Coastal conservation and management: an ecological perspective; 2001. p. 25-52.

Gann GD, Lamb D. Ecological restoration: a means of conserving biodiversity and sustaining livelihoods. A call to action by the ecological restoration joint working group of SER. In: Gann GD, Lamb D, editors. Ecological Restoration. Arizona: Society for Ecological Restoration International and International Union for Conservation of Nature and Natural Resources; 2006. p. 6.

Goldsmith FB. The vegetation of exposed sea cliffs at South Stack, Anglesey: II. Experimental studies. J Ecol. 1973;61(3):819-29.

Han YU. The characteristics of halophyte vegetation of salt marshes in the southern and western coasts of Korea (PhD dissertation). Muan: Mokpo National University; 2008.

Hepburn I. A study of the vegetation of sea-cliffs in North Cornwall. J Ecol. 1943; 31(1):30-9.

Ihm BS. Distribution of coastal plant communities in response to soil water potential and plant osmotic adjustment (PhD dissertation). Seoul: Seoul National University; 1989.

Ihm BS, Lee JS, Kim JW, Kim HS, Ihm HB. Studies on the vegetation at the wetland of Suncheon-Man. Bull Inst Litt Envi Mokpo Natl Univ. 1998a;15:1-8.

Ihm BS, Lee JS, Kim JW, Kim HS, Ihm HB. Studies on the vegetation distribution and biomass at the wetland of Hampyung-Man. Bull Inst Litt Envi Mokpo Natl Univ. 1998b;15:9-20.

Jones L, Garbutt A, Hansom J, Angus S. Impacts of climate change on coastal habitats. MCCIP Science Review. 2013:167-79.

Jung YK, Kim JW. A comparative study on mantle communities in South Korea and Japan. Kor J Env Eco. 1998;21(1):81-8.

Kennedy DM, Dickson ME. Cliffed coasts of New Zealand: perspectives and future directions. J R Soc N Z. 2007;37(2):41-57. https://doi.org/10.1080/ 03014220709510535

Kim CH, Lee KB, Kim JD, Cho TD, Lim MS. The study on the flora and vegetation of salt marshes of Dongjin-river estuary in Jeonbuk. J Environ Sci Int. 2005;14:817-25.

Kim HJ, Shin HS, Han SH, Ko SY, Kang HJ, Lee SH, Lee CY, Kim CB, Bae YT, Shin JK, Yun $\mathrm{CW}$. Type classification of vegetation on the coastal sand dune and comparisons of mineral nutrients in soil and plant. J Korean For Soc. 2013;102(3):345-54.

Kim HS. Vegetation and value grade for vegetation conservation in the uninhabited island: case studies in southwestern coast of Jeollanam-do. Nat Conserv. 2012;160:34-45.

Kim HS, Cho JS, Lee JH, Lee JS. Soil environment of halophyte habitat in golaebul coastal sand-dunes of east coast. J Korean isl. 2009;21:333-40.

Klaudisova A, Osbornova J. Abandoned fields in the region. In: Osbornova J, Kovarova M, Leps J, Prach K, editors. Succession and abandoned fields: studies in Central Bohemia, Czechoslovakia. Dordrecht: Kluwer Academic Publisher; 1990. p. 7-21.
Korea Meteorological Administration. Climatological normals of Korea: 19812010. Seoul: Korea Meteorological Administration; 2011.

Korea National Arboretum. Korean Plant Names Index. 2003. http://www.nature. go.kr/kbi/plant/pilbk/selectPlantPilbkGnrlList.do. Accessed 11 Jan 2018.

Larson DW, Matthes U, Kelly PE. Cliff ecology: pattern and process in cliff ecosystems. New York: Cambridge University Press; 2005.

Lee CS, Kim HE, Park HS, Kang SJ, Cho HJ. Structure and maintenance mechanism of Koelreuteria Paniculata community. J Ecol Environ. 1993;16(4): 377-95.

Lee HJ, Kim JH, Chun YM, Jeong HR. Community ecology on forest vegetation in Yeongjongdo island. Kor J Env Eco. 2003;26(5):223-36.

Lee JS. On establishment of halophytes along tidal level gradient at salt marshes of Mankyong and Dongjin river estuaries (PhD dissertation). Seoul: Seoul National University; 1989.

Lee JS, IIm BS, Myeong HH, Park JW, Kim HS. Soil environment analysis and habitat of halophyte for restoration in the salt marshes of southern and western coasts of Korea. Korean J Plant Res. 2009;22:102-10.

Lee JS, Kim JK. Factors affecting plant distribution in salt marsh of Mankyong river and Donjin river estuaries. Nat Sci Res Kunsan Natl Univ. 1988;3:45-59.

Lee SM, Cho YC, Lee CS. Feasibility of seed bank for restoration of salt marsh: a case study around the Gwangyang Bay, southern Korea. Kor J Env Eco. 2012; 35(2):1-7.

Lee TB. Illustrated Flora of Korea. Hyangmoonsa: Seoul; 1985.

McDonald T, Gann GD, Jonson J, Dixon KW. International standards for the practice of ecological restoration - including principles and concepts. 1st ed. Washington DC: Society for Ecological Restoration; 2016.

Millenium Ecosystem Assessment. Ecosystem and human well-being. Millenium Ecosystem Assessment; 2005.

Min BM. Changes of soil and vegetation in coastal reclaimed lands, west coast of Korea (PhD dissertation). Seoul: Seoul National University; 1985.

Naveh Z. From biodiversity to ecodiversity: a landscape-ecology approach to conservation and restoration. Restor Ecol. 1994;2(3):180-9.

Park SH. Colored illustrations of naturalized plants of Korea. Ilchokak: Seoul; 1995.

Partridge TR, Wilson JB. Plant communities at Aramoana. In: The ecology of Aramoana, Otago Harbour. Dunedi: Dunedin Metropolitan Regional Planning Authority; 1975.

Primack RB. A primer of conservation biology. Fourth edition. Sunderland: Sinauer Associates Inc; 2008.

Ramesh R, Srinivasalu S, Sathya S, Rajalakshmi K, Kumaravel P. Coastal cliffs of India. ENVIS - MOEF\&CC Newsletter on Coastal Zone Management and Coastal Shelter Belt. 2017;16(1):1-27.

Rozema J, Van Manen Y, Vugts HF, Leusink A. Airborne and soilborne salinity and the distribution of coastal and inland species of the genus Elytrigia. Acta Bot Neerl. 1983:32(5-6):447-56.

Shin HS, Kim TG, Yun CW. Phytosociological vegetation classification and flora for the mid-west coast in Korea. J Apic. 2015;30(4):315-29.

Song HS, Cho W, Ahn YH. Vegetation at sea cliffs of uninhabited islets of Ganghwa-gun. Korea Kor J Env Eco. 2008;22:453-60.

Song HS, Cho W, Park YJ. Distribution pattern of growth plants with Peucedanum japonicum Thunb. Community in sea cliff plants, Korea. Kor J Env Eco. 2009;23:346-52.

SPSS for Windows, V. 12.0, SPSS Inc., Copyright@2003, Chicago, IL, USA.

Stolton S, Dudley N, Avcıoğlu ÇB, Hunter D, Ivanić KZ, Kanga E, Kettunen M, Kumagai Y, Maxted N, Senior J, Wong M, Keenleyside K, Mulrooney D, Waithaka J. Values and benefits of protected areas. In: Worboys GL, Lockwood M, Kothari A, Feary S, Pulsford I, editors. Protected area governance and management. Canberra: ANU Press; 2015. p. 145-68.

Ter Braak CJF. CANOCO: a FOTRAN program for canonical community ordination by (partial) (detrended) (canonical) correspondence analysis, principle component analysis, and redundancy analysis (Version 2.1). Wageningen: TNO Institute of Applied Computer Science; 1987. p. 126.

Wilson JB, Cullen C. Coastal cliff vegetation of the Catlins region Otago, South Island, New Zealand. NZ J B. 1986:24(4):567-74. 